\title{
Drying kinetics of jabuticaba pulp by regression models
}

\author{
Thais Destefani Ribeiro Furtado ${ }^{1}$, Joel Augusto Muniz ${ }^{2}$, \\ Edilson Marcelino Silva ${ }^{3}$, Jaqueline Gonçalves Fernandes ${ }^{4}$
}

\begin{abstract}
Jabuticaba tree is native to the Atlantic Forest in Southern Brazil, and its fruit is widely consumed in the fresh form, but it is highly perishable, requiring conservation techniques. The aim of this study was to describe the drying kinetics of jabuticaba pulp at temperatures of 50 and $60^{\circ} \mathrm{C}$, comparing the Henderson, Simple Three-Parameter Exponential, Lewis, Thompson, Fick and Wang and Sing regression models and estimating the Absolute Drying Rate (ADR) for the best model. Parameters were estimated using the SAS software. The evaluation of the quality in the adjustment and selection of models was made based on the adjusted determination coefficient, Residual Standard Deviation and Akaike Information Criterion. Models presented good adjustment to data, and the Lewis model was the most suitable to describe the drying kinetics of jabuticaba pulp at temperatures of 50 and $60^{\circ} \mathrm{C}$, with drying rate of 0.000063 and $0.000082 \mathrm{~g}$ of water/s respectively. ADR indicated that in one third of the drying time, $70 \%$ of moisture loss occurred at both temperatures and after this period, there was a deceleration of moisture loss until stabilization, when equilibrium moisture content is reached.
\end{abstract}

Index terms: food preservation; moisture ratio; nonlinear regression; statistical models.

\section{Cinética de secagem de polpa de jabuticaba por modelos de regressão}

Corresponding author: t.destefani.ribeiro@gmail.com

Received: August 31, 2018 Accepted: November 26, 2018

Copyright: All the contents of this journal, except where otherwise noted, is licensed under a Creative Commons Attribution License.

\section{$(c c) E_{Y}$}

Resumo-A jabuticabeira é nativa da Mata Atlântica no Sul do Brasil, e seu fruto é muito consumido in natura, no entanto é altamente perecível, necessitando de técnicas de conservação. Objetivou-se descrever a cinética de secagem de polpa de jabuticaba nas temperaturas de 50 e $60^{\circ} \mathrm{C}$, comparando os modelos de regressão Henderson, Exponencial Simples com Três Parâmetros, Lewis, Thompson, Fick e Wang e Sing e, obtendo a Taxa de Secagem Absoluta (TSA) para o melhor modelo. A estimação dos parâmetros foi realizada com o software SAS. A avaliação da qualidade no ajuste e na seleção dos modelos foi feita com base no coeficiente de determinação ajustado, Desvio Padrão Residual e Critério de Informação de Akaike. Os modelos apresentaram bom ajuste aos dados, sendo que o modelo de Lewis foi o mais indicado para descrever a secagem da polpa de jabuticaba nas temperaturas de 50 e $60^{\circ} \mathrm{C}$, com taxa de secagem de 0,000063 e $0,000082 \mathrm{~g}$ de água/s respectivamente. A TSA indicou que em um terço do tempo de secagem ocorreram de $70 \%$ da perda de umidade nas duas temperaturas e, após este período, houve desaceleração da perda de umidade até que se estabilizou ao alcançar o teor de umidade de equilíbrio.

Termos de Indexação: conservação de alimentos; razão de umidade; regressão não linear; modelos estatísticos.

${ }^{1} \mathrm{PhD}$ student in Agricultural Statistics and Experimentation, Federal University of Lavras/ Lavras-MG, Brazil. E-mail: t.destefani.ribeiro@ gmail.com (ORCID 0000-0002-6402-5202)

${ }^{2} \mathrm{PhD}$ in Agricultural Statistics and Experimentation, Full Professor in Federal University of Lavras/Lavras-MG, Brazil. E-mail: joamuniz@ des.ufla.br (ORCID 0000-0002-1069-4136)

${ }^{3} \mathrm{PhD}$ student in Agricultural Statistics and Experimentation, Federal University of Lavras/ Lavras-MG, Brazil .E-mail: edilsonmg3@hotmail. com (ORCID 0000-0002-2800-3495)

${ }^{4} \mathrm{PhD}$ student in Agricultural Statistics and Experimentation, Federal University of Lavras/Lavras-MG, Brazil. E-mail: jaqgonfer@gmail.com (ORCID 0000-0002-7236-9718) 


\section{Introduction}

Jabuticaba tree (Myrciaria spp. Berg) is a fruit tree native to the Atlantic Forest in southern Brazil, with subtropical climate by origin, which develops well on soils with good water supply, and its flowering occurs more than once a year, between the end of winter and beginning of spring (EMBRAPA FLORESTAS, 2015). According to Alves et al. (2014), jabuticaba cultivation is found from the state of Pará to Rio Grande do Sul. Among the cultivars used, the one that most occurs in Brazil is 'Sabará' cultivar (NUNES et al., 2014; GOBATO et al., 2018).

Jabuticaba fruit has high levels of carbohydrates, vitamin $\mathrm{C}$, fibers and iron ( $\mathrm{Fe}$ ), among other compounds that are necessary for a healthy diet according to the Brazilian Table of Food Composition (TACO, 2011). In addition to being rich in nutrients, jabuticaba presents pleasant sensory characteristics for fresh consumption, as well as in the form of jellies, liqueurs, fermented beverages and vinegar, with high economic potential (CORADIN et al., 2011; VIEIRA et al., 2017; GOBATO et al., 2018).

In general, the marketing of jabuticaba is carried out in small regional stores and in poor storage conditions, which compromises the quality of fruit and changes its physical characteristics, such as wilting, weight loss, bark wrinkling as well as its sensory characteristics, such as pulp darkening, making it bitter. Under these conditions, jabuticaba is highly perishable, with shelf life of 2 to 3 days, accelerating the loss of the commercial value of fruits and thus reaching high market values (ZICKER, 2011; VIEIRA et al., 2017).

Considering the rapid deterioration of jabuticaba and the difficulty of preservation, the extraction of pulp for drying adds value to the product in the food industry and allows access in off-season periods. Thus, the drying process of jabuticaba pulp emerges as an alternative to increase its shelf life, as it provides reduction in the amount of water, resulting in extended shelf life with a decrease in microbial activity.

The drying process consists of the removal of water or any other liquid from the food in the form of vapor to the unsaturated air (MORAES; RODRIGUES, 2006). In studies with drying of star fruit pulp, Silva et al. (2016), observed that the relationship between the moisture content in the pulp and the drying time can be described in a drying curve at decreasing rate, schematically divided into four periods. These periods are, first: initial drying phase, which goes until the food reaches the wet bulb temperature; second: constant speed, occurs until the food has critical moisture content; third: first decreasing speed range; fourth: second decreasing speed range, until equilibrium moisture content is reached.

According to Silva et al. (2016) and Siqueira et al. (2013), the use of mathematical models to represent the drying process of agricultural products is of fundamental importance, since the information generated allows the reduction of time and costs in the process, as well as predicting drying times and developing equipment with the purpose of obtaining final product with greater durability and quality.

Drying curves may be concave, convex or approaching a straight line, and may also present an inflection point when a change in the physical form of the material occurs, for example, when contraction and rupture occurs or a film forms on the surface of the partially dried material (GOUVEIA et al., 2003). These curves are in a sigmoid format and can be described by non-linear regression models.

The estimation of parameters in nonlinear models is based on the minimization of the sum of squared of residuals, obtaining the system of normal nonlinear equations, whose solution requires the use of iterative methods. Among iterative procedures, the most common is that of Gauss-Newton (RIBEIRO et al., 2018a; MUIANGA et al., 2016; MUNIZ et al., 2017; GUEDES et al., 2004; MAZZINI et al., 2003). An important feature of nonlinear models is that, for suitable adjustments, parameter estimates present a practical and predictive interpretation based on experimental data analyzed (MAZZINI et al., 2005). In kinetic drying studies, nonlinear modeling allows informing the drying rate value and its confidence interval, providing credibility to predictions.

This work aimed to evaluate the adjustment of the Henderson, Lewis, Thompson, Fick, Simple threeparameter Exponential nonlinear models, and the Wang and Sing linear model in the description of the drying kinetics of jabuticaba pulp at different temperatures, and to estimate the absolute pulp drying rate for the most appropriate model.

\section{Materials and methods}

For the accomplishment of the present work, part of data related to the drying of jabuticaba pulp obtained by Nunes et al. (2014) was used. The experiment was carried out at the Laboratory of Storage and Processing of Agricultural Products (LAPPA), at the Academic Unit of Agricultural Engineering (UAEA) - Federal University of Campina Grande (UFCG), located in Campina Grande, PB. As described by the authors, fruits were purchased at local market, sanitized, and the pulp was extracted and homogenized. After these procedures, samples were submitted to thin-layer drying process in a forced air oven at temperatures of $50^{\circ} \mathrm{C}$ and $60^{\circ} \mathrm{C}$. The moisture content of samples was measured until equilibrium moisture content was reached up to $64440 \mathrm{~s}$ (1075 min) with 28 measurements and 33000 (550 $\mathrm{min})$ with 23 measurements at temperatures of $50^{\circ} \mathrm{C}$ and $60^{\circ} \mathrm{C}$ respectively . Experimental data were adjusted to Henderson $(\mathrm{H})$, Lewis (L), Simple Three-Parameter Exponential (ESTP), Thompson (T) and Fick (F) nonlinear regression models and Wang and Sing (WS) linear model as described by 
equations, respectively: $M R_{i}=k_{0} \exp \left(-k_{1} t_{i}\right)+u_{i}$

$M R_{i}=\exp \left(-k_{1} t_{i}\right)+u_{i}(2) \quad M R_{i}=k_{0} \exp \left(-k_{1} t_{i}\right)+k_{2}+u_{i}$ $M R_{i}=\left(\exp \left(-a-\left(a^{2}+4 b t_{i}\right)^{0.5}\right) / 2 b\right)+u_{i}$

$M R_{i}=\frac{6}{\pi^{2}} \sum_{n=1}^{i} \frac{1}{n^{2}} \exp \left(-n^{2} \pi^{2} D_{e f} \frac{1}{t_{i}}\right)+u_{i}(5) ; \quad M R_{i}=1+a t_{i}+b t_{i}^{2}+u_{i}$

in which, with $\mathrm{i}=1,2, \ldots, \mathrm{n}$, where $\mathrm{n}=28$ at temperature of $50^{\circ} \mathrm{C}$ and $\mathrm{n}=23$ at temperature of $60^{\circ} \mathrm{C}$, times in which the moisture in jabuticaba pulp was measured; $u_{i}$ is the residue of the adjustment in the $\mathrm{i}$-th time; $\phi_{1}$ is the autoregressive parameter of order $1 ; u_{i-1}$ is the residue of the time adjustment immediately preceding the $i$-th measure; $\phi_{p}$ is the autoregressive parameter of order $\mathrm{p} ; u_{i-p}$ is the residue of the adjustment at $\mathrm{p}$ times before the $\mathrm{i}$-th measure; $\varepsilon$ is the white residual with normal distribution $\mathrm{N}\left(0, \sigma^{2}\right)$ When residuals are independent, parameter $\phi_{1}$ will be null, and consequently $u_{i}=\varepsilon_{i}$ (MAZZINI et al., 2005; GUEDES et al., 2004; RIBEIRO et al., 2018a; MUNIZ et al., 2017; PRADO et al., 2013).

In equations (1), (2), (3), (4), (5) and (6), $M R_{i}$ describes the mean value of the moisture ratio (dimensionless) of jabuticaba pulp in time $i$ in days; $k_{0}$ corresponds to the initial fruit condition, being close to 1 because it represents $100 \%$ of the initial pulp moisture; $k_{l}$ represents the drying rate, which can also be obtained by differentiation, refers to the variation of the moisture loss by the process time, with values between 0 and 1 , since the moisture loss is always lower than the drying period; $k_{2}$ corresponds to a dimensionless model adjustment parameter; $D_{e f}$ is the Effective Diffusivity $\left(\mathrm{m}^{2} \mathrm{~s}^{-1}\right) ; a$ and $b$ are the regression coefficients of the linear model; exp the basis of the Neperian logarithm. In order to adjust models to data, the proc model, proc nlmixed and proc nlin procedures of the Statistical Analysis System software (SAS, 2018) were used, and the graphics generated with the "gplots" package (WARNES et al., 2016) of the R software (R DEVELOPMENT CORE TEAM, 2018) using the modified Gauss-Newton method.

The assumptions required for validity of the statistical model were verified by applying the DurbinWatson test in order to evaluate the existence of residual autocorrelation, and the Shapiro-Wilk (SW) and BreushPagan (BP) tests for the verification of the normality and homogeneity of residuals, respectively, as well as the graphic analysis of residuals. As evaluators of the adjustment quality, the determination coefficient, adjusted for the mean $\left(\mathrm{R}^{2}{ }_{\mathrm{aj}}\right)$, and the residual standard deviation, (RSD) were used. According to Fernandes et al. (2014), the higher the $\mathrm{R}^{2}$ aj value and the lower the RSD, the better the model adjusts to data. As a criterion for selecting models, the Akaike Information Criterion (AIC) was used, and the model chosen was the one that presented the lowest AIC value (RIBEIRO et al., 2018b; FERNANDES et al., 2014).

After adjusting models to data, the t-student test was applied to verify the significance of estimates obtained for parameters and the confidence interval at $95 \%$ confidence level was calculated. Subsequently, a drying curve study was performed, obtaining the Absolute Drying
Rate (ADR) through the first and second derivative of the most appropriate model, following the considerations of Dalpasquale et al. (2009), regarding the drying rate concepts. It is possible to infer about the changes in the drying process, such as to indicate up to the moment the slower or faster moisture loss occurred, and how this occurs.

\section{Discussion results}

Results were presented in two parts, first adjusting models to data and then the results obtained in relation to the absolute drying rate of jabuticaba pulp at both temperatures. The Fick diffusivity model did not converge, so its results do not appear in tables and figures. Table 1 presents the Shapiro-Wilk, Breuch-Pagan and DurbinWatson tests, with their respective significance, and Figures 1 and 2 present the residual analysis graphs for the following models: Henderson (H), Lewis (L), Single Three-Parameter Exponential (ESTP), Thompson (T) and Wang and Sing (WS) for data at temperatures of 50 and $60{ }^{\circ} \mathrm{C}$ respectively.

The Durbin-Watson test was generally significant, indicating residual autocorrelation at both temperatures, that is, there was residual dependence over time. This result was expected, as measurements were performed on the same jabuticaba pulp material over time. In studies with fruit growth, similar results were found by Muniz et al. (2017), Muianga et al. (2016) and Ribeiro et al. (2018a), who observed the presence of autocorrelated errors in the adjustment of nonlinear regression models for the description of the growth of cacao, cashew and Asian pear fruits, respectively. According to these authors, whenever residual dependence is observed, this correlation must be modeled by an autoregressive process. Different results were found by Ribeiro et al. (2018b) with the growth of pequi fruits, since no residual dependence was observed because biometric measurements were made in different fruits at each age.

After the study on residual dependence, it was found that the Shapiro-Wilk and Breuch-Pagan tests were, in general, not significant in both temperatures, and that the residual values are normally distributed and with homogeneous variance, except for the Wang and Sing model at $50^{\circ} \mathrm{C}$ and Thompson at $60^{\circ} \mathrm{C}$. The same can be observed in Figures 1 and 2 in models where tests were significant for normality and homogeneity of variances, it was possible to observe a pattern in figures, suggesting the violation of assumptions and thus corroborating the results of Table 1. According to Fernandes et al. (2015), the verification of the assumptions for regression models are very important, since if they are not met, the model is not adequate and this deviation must be corrected or considered in the model. The models of Wang and Sing at $50^{\circ} \mathrm{C}$ and Thompson at $60^{\circ} \mathrm{C}$ were not considered adequate to describe data at these temperatures, and for 
the other models, the autoregressive error of order 1 was included to correct the residual dependence. The estimates with respective $95 \%$ confidence intervals probability for the parameters of Henderson, Lewis and Simple Threeparameter Exponential, Thompson and Wang and Sing models at both temperatures are presented in Table 2.

Based on the parameter $k_{0}$ estimates presented in Table 2, it was observed that the values obtained were close to 1 at both temperatures, as expected, since they refer to $100 \%$ of the initial moisture content of jabuticaba pulp, as described by Nunes et al. (2014). Silva et al. (2016) studied the drying of star fruit pulp and values close to 1 for $k_{0}$ when adjusting the Henderson model. Considering the parameterization of the WS model at the beginning of the process at $n=1$ (time zero seconds), the model presents moisture ratio equal to 1 , as estimated by nonlinear models, and the model $\mathrm{T}$ has no explicit relation with values. The estimates for parameter $k_{1}$ were between zero and one, as they represent the drying rate of the product, which is given by the ratio between moisture variation and the drying time variation.

Considering the values observed in Table 2 , the drying rates at temperatures of $50^{\circ} \mathrm{C}$ and $60^{\circ} \mathrm{C}$ were $0.000063 \mathrm{~g}$ of water $/ \mathrm{s}(0.0038 \mathrm{~g}$ of water $/ \mathrm{min})$ and $0.000082 \mathrm{~g}$ of water $/ \mathrm{s}(0.0049 \mathrm{~g}$ water $/ \mathrm{min})$ respectively. As can be seen, with increasing temperature, $k_{l}$ increases, i.e., the moisture loss rate of jabuticaba pulp, over time, is higher with the increase in drying temperature. This corroborates the results obtained by Gouveia et al. (2003) in studies with the drying curve of cajá, because temperature is one of the factors of greatest influence in the drying process, and the higher the temperature, the shorter the drying time and, consequently, the faster the equilibrium moisture content (ME) of the product is reached. Similar results were found by Pena and Mendonça (2009) in the drying processes of passion fruit residual fiber, by Borges et al. (2008), with the drying kinetics of pumpkin slices and Silva et al. (2016) with star fruit pulp.

In relation to the linear model $\mathrm{WS}$ at $50^{\circ} \mathrm{C}$, the negative $a$ parameter makes an inference under the slope of the curve and has value in modulus close to that of parameter $k_{1}$ of models mentioned above, considering the variation in relation to the moisture loss occurred in the curve. The Thompson model does not present similarity to the other models in the estimation of their parameters. The confidence intervals presented small amplitude for parameter $k_{0}$, and in both temperatures, indicating quality in the adjustment of models to data (RIBEIRO et al., 2018 a,b). Parameter $k_{2}$, present in the ESTP model, was not significant at both temperatures, indicating that it was considered null, since its Confidence Interval assumes the value zero, making it invalid for the model. When performing the re-parameterization of the Simple Three-Parameter Exponential model, it assumes the parameterization of the Henderson model. Thus, ESTP can be discarded in the adjustment to data in both temperatures, as they become two identical models.

The use of autoregressive errors has as a characteristic to improve the quality of adjustment of models when they are necessary, making estimated values to have higher reliability and lower standard deviation (MUNIZ et al., 2017; MUIANGA et al., 2016). The firstorder autoregressive component $\left(\emptyset_{1}\right)$, used to describe the residual autocorrelation identified in data, was highly significant for all models present in Table 2, and with estimates close to 0.9100 at temperature of $50^{\circ} \mathrm{C}$ and 0.9300 at temperature of $60^{\circ} \mathrm{C}$. The results indicated a high first-order positive correlation among residues at both temperatures, which corresponds to the strong correlation among observations over time, reaffirming the need to be considered in the adjustment of models to data.

Table 3 presents the adjustment quality evaluators $\mathrm{R}_{\text {aj }}^{2}$, RSD, and the AIC selection criteria for the models that adjusted to the drying kinetic data of jabuticaba pulp at temperatures of 50 and $60^{\circ} \mathrm{C}$. The estimated values for the adjusted determination coefficient were above 0.99 , and those of low PRD, on the order of $10^{-4}$, indicating quality in the adjustment. Borges et al. (2011), in studies with banana drying kinetics observed $\mathrm{R}^{2}$ values above 0.93 and standard error of the order of $10^{-2}$, indicating quality in the adjustment of the simple exponential model with two parameters, which has the same parameterization of the Henderson model and a simple linear model. Pena and Mendonça (2009), in studies with passion fruit fiber residue, found $\mathrm{R}^{2}$ values above 0.94 for the Lewis model, and considered quality in the adjustment.

In general, the models presented similar adjustments, with only Lewis and Henderson models adjusted to data at both temperatures. The AIC selection criterion, presented in Table 3, indicated the Lewis model as the most correct to describe the drying data of jabuticaba pulp at both temperatures, with lower values for the criterion. Muniz et al. (2017) and Ribeiro et al. (2018a), used the AIC selection criterion to compare nonlinear regression models to describe the growth of cocoa and Asian pear fruits, respectively, and observed that lower AIC values indicated the nonlinear regression model as the most adequate to describe data.

The adjustment of the Lewis model at temperatures of 50 and $60^{\circ} \mathrm{C}$ can be visualized in Figure 3, with its confidence intervals. At both temperatures, the adjustment of the Lewis model was close to the values observed, indicating quality in the adjustment, as was observed with the quality evaluators in Table 3 . It is possible to observe in Figure 3 the phases of the drying processes, which start at time 0 seconds. In (a), with up to approximately 9600 seconds (160 minutes), the product reaches the equilibrium temperature, followed by the other drying phases, being the loss of constant humidity and loss of moisture at a decreasing rate up to the end of the process, when equilibrium moisture content of about 60,000 seconds (1000 minutes) is observed up to 64440 seconds (1.074 
minutes), without significant change. In (b), it is possible to observe the initial drying phase in which the product reaches the equilibrium temperature in about 4800 seconds (80 minutes), followed by the drying phases, through the decreasing rate and stabilization of equilibrium moisture at end of the process with approximately 30.000 seconds (500 minutes) and is observed up to 33000 seconds (550 minutes) without significant change.

It was observed that with the $10^{\circ} \mathrm{C}$ increase in temperature, there was a $50 \%$ decrease in the drying time. Similar results were obtained by Madureira et al. (2011) with the drying of prickly pear pulp with addition of modified starch, since with the increase in drying temperature of $10^{\circ} \mathrm{C}$ from $50^{\circ} \mathrm{C}$ to $60^{\circ} \mathrm{C}$, there was a decrease of about $30 \%$ in the drying time. The authors evaluated the drying process at temperatures of $50^{\circ} \mathrm{C}$ and $60^{\circ} \mathrm{C}$ until times of approximately 630 minutes and 440 minutes, respectively, under the described conditions. Gouveia et al. (2003) in their studies with the drying curve of cajá, also observed faster moisture loss at the beginning of the process and, after a certain period, deceleration in the moisture loss, being that the total period in the determination of the drying curve at $50^{\circ} \mathrm{C}$ was 38 hours and at $80^{\circ} \mathrm{C}, 9$ hours, indicating the temperature as the main factor for the decrease in drying time.

In the drying phase with constant moisture loss, it was observed that increasing the temperature reduces this phase, indicating that a significant amount of water is present in the free form in jabuticaba pulp and the other portion interacts with soluble solids. Similar results were found by Pena and Mendonça (2009) in their studies with the drying of passion fruit residual fiber. The decrease in drying time is due to the increase in temperature and, in economic terms, it would be better for the producer, since it optimizes process and reduces production costs. However, in order to decide the best drying temperature, it is also necessary to carry out chemical, physical and biological analyses on the final product.

After the choice of the Lewis model, the Absolute Drying Rate (ADR), which can be visualized in Figure 4 , in (a) and (b), was obtained for the pulping processes of jabuticaba pulp at temperatures of $50^{\circ} \mathrm{C}$ and $60^{\circ} \mathrm{C}$ respectively. It was observed that, at $50^{\circ} \mathrm{C}$, (a), there was greater moisture loss in the range from 0 to 21000 seconds ( 0 to 350 minutes), during which $70 \%$ of the drying process occurred. After this interval, there was deceleration of the moisture loss until stabilization was reached at the end of the process. In (b), ADR indicated the accelerated moisture loss in the period from 0 to 15000 seconds ( 0 to 250 minutes), where $70 \%$ of the moisture loss occurred, and as in (a), there was deceleration in the moisture loss after this period. Madureira et al. (2011) also observed that after the more pronounced moisture loss, there is deceleration of moisture loss until process stabilization. The fastest moisture loss in the initial period can be visually observed, followed by deceleration until process stabilization. Silva et al. (2016) and Gouveia et al. (2003) found that after final stabilization in the equilibrium moisture content of the drying process, moisture loss can only be altered if the process conditions such as temperature and drying air velocity are modified.

Table 1. P-values for the Shapiro-Wilk (SW), Breuch-Pagan (BP) and Durbin-Watson (DW) tests with their respective significance in the analysis of estimated residuals after adjustment of the models, Henderson $(\mathrm{H})$, Simple ThreeParameter Exponential (ESTP), Lewis (L), Thompson (T) and Wang and Sing (WS) models to the drying kinetics data of jabuticaba pulp at temperatures of 50 and $60^{\circ} \mathrm{C}$.

\begin{tabular}{|c|c|c|c|}
\hline Models & SW & $\mathrm{BP}$ & DW \\
\hline \multicolumn{4}{|c|}{ Temperature of $50^{\circ} \mathrm{C}$} \\
\hline $\mathrm{H}$ & $0.4639^{\mathrm{ns}}$ & $0.1374^{\mathrm{ns}}$ & $0.0010^{*}$ \\
\hline $\mathrm{L}$ & $0.6054^{\mathrm{ns}}$ & $0.5101^{\mathrm{ns}}$ & $0.0010^{*}$ \\
\hline ESTP & $0.3370^{\mathrm{ns}}$ & $0.3138^{\mathrm{ns}}$ & $0.0010 *$ \\
\hline $\mathrm{T}$ & $0.4635^{\mathrm{ns}}$ & $0.1378^{\mathrm{ns}}$ & $0.0010^{*}$ \\
\hline WS & $0.8187^{\mathrm{ns}}$ & $0.0012 *$ & $0.0010 *$ \\
\hline \multicolumn{4}{|c|}{ Temperature of $60^{\circ} \mathrm{C}$} \\
\hline $\mathrm{H}$ & $0.1713^{\mathrm{ns}}$ & $0.0894^{\mathrm{ns}}$ & $0.0010^{*}$ \\
\hline $\mathrm{L}$ & $0.1504^{\mathrm{ns}}$ & $0.8505^{\mathrm{ns}}$ & $0.0010 *$ \\
\hline ESTP & $0.2816^{\mathrm{ns}}$ & $0.4299^{\mathrm{ns}}$ & $0.0010^{\mathrm{ns}}$ \\
\hline $\mathrm{T}$ & $0.1717^{\mathrm{ns}}$ & $0.0104 *$ & $0.0010^{\mathrm{ns}}$ \\
\hline WS & $0.3553^{\mathrm{ns}}$ & $0.9981^{\mathrm{ns}}$ & $0.0010^{\mathrm{ns}}$ \\
\hline
\end{tabular}

* Significant at $5 \%$ probability level by respective SW, BP and DW tests.

${ }^{\text {ns }}$ Not significant in relation to respective SW, BP and DW tests. 
Table 2. Estimations of parameters, with their respective confidence intervals (UL and LL), for the Henderson (H), Simple Three-Parameter Exponential (ESTP), Lewis (L), Thompson (T) and Wang and Sing (WS) models for the drying kinetics data of jabuticaba pulp at temperatures of 50 and $60^{\circ} \mathrm{C}$, considering first-order autoregressive errors.

\begin{tabular}{|c|c|c|c|c|c|}
\hline Temperature & Models & Parameters & Estimates & UL & LL \\
\hline \multirow{12}{*}{$50^{\circ} \mathrm{C}$} & \multirow{3}{*}{$\mathrm{H}$} & $\mathrm{k}_{0}$ & $0.9995 * *$ & 0.9500 & 1.0491 \\
\hline & & $\mathrm{k}_{1}$ & $0.000063^{* *}$ & 0.000042 & 0.000085 \\
\hline & & $\emptyset$ & $0.9186^{* *}$ & 0.7316 & 1.1057 \\
\hline & \multirow{2}{*}{$\mathrm{L}$} & $\mathrm{k}_{1}$ & $0.000063 * *$ & 0.000043 & 0.000083 \\
\hline & & $\emptyset$ & $0.9182 * *$ & 0.7351 & 1.1014 \\
\hline & \multirow{4}{*}{ ESTP } & $\mathrm{k}_{0}$ & $0.9807 * *$ & 0.8068 & 1.1546 \\
\hline & & $\mathrm{k}_{1}$ & $0.000065^{* *}$ & 0.000032 & 0.000097 \\
\hline & & $\mathrm{k}_{2}$ & 0.0189 ns & -0.1501 & 0.1879 \\
\hline & & $\emptyset_{-1}$ & $0.9256^{* *}$ & 0.7045 & 1.1467 \\
\hline & \multirow{3}{*}{$\mathrm{T}$} & $\mathrm{a}$ & $2.3242 * *$ & 2.1291 & 2.5194 \\
\hline & & $\mathrm{b}$ & $0.000080^{* *}$ & 0.000048 & 0.000117 \\
\hline & & $\varnothing_{1}$ & $0.9575 * *$ & 0.8289 & 1.0861 \\
\hline \multirow{12}{*}{$60^{\circ} \mathrm{C}$} & \multirow{3}{*}{$\mathrm{H}$} & $\mathrm{k}_{0}$ & $1.0032 * *$ & 0.9606 & 1.0458 \\
\hline & & $\mathrm{k}_{1}$ & $0.000082 * *$ & 0.000052 & 0.000117 \\
\hline & & $\emptyset_{1}$ & $0.9315 * *$ & 0.7097 & 1.1533 \\
\hline & \multirow{2}{*}{$\mathrm{L}$} & $\mathrm{k}_{1}$ & $0.000082^{* *}$ & 0.000050 & 0.000113 \\
\hline & & $\emptyset_{-1}$ & $0.9333 * *$ & 0.7130 & 1.1536 \\
\hline & \multirow{4}{*}{ ESTP } & $\mathrm{k}_{0}$ & $1.0371 * *$ & 0.8603 & 1.2139 \\
\hline & & $\mathrm{k}_{1}$ & $0.000078^{* *}$ & 0.000037 & 0.000123 \\
\hline & & $\mathrm{k}_{2}$ & $-0.0341 \mathrm{~ns}$ & -0.2094 & 0.1412 \\
\hline & & $\emptyset_{1}^{2}$ & $0.9203 * *$ & 0.6315 & 1.2092 \\
\hline & \multirow{3}{*}{ WS } & $\mathrm{a}$ & $-0.000064 * *$ & -0.000072 & -0.000060 \\
\hline & & $\mathrm{b}$ & $1.04 \times 10^{-9 * *}$ & $9.9 \times 10^{-10}$ & $1.1 \times 10^{-9}$ \\
\hline & & $\emptyset_{1}$ & $0.8657 * *$ & 0.6104 & 1.1210 \\
\hline
\end{tabular}

**Highly significant in relation to Student t-test (1\% alpha); ns Not significant in relation to t-Studant test. UL-Upper Limit; LL-Lower Limit.

Table 3. Performance quality evaluators of the Henderson (H), Lewis (L), Thompson (T) and Wang and Sing (WS) models with $\emptyset_{1}$ component, referring to the drying kinetics data of jabuticaba pulp at temperatures of 50 and $60^{\circ} \mathrm{C}$.

\begin{tabular}{ccccccc}
\hline & \multicolumn{3}{c}{$\mathrm{R}^{2}$} & \multicolumn{3}{c}{$\mathrm{RSD}$} \\
Model & $50^{\circ} \mathrm{C}$ & $60^{\circ} \mathrm{C}$ & $50^{\circ} \mathrm{C}$ & $60^{\circ} \mathrm{C}$ & $50^{\circ} \mathrm{C}$ & $60^{\circ} \mathrm{C}$ \\
\hline $\mathrm{H}$ & 0.9953 & 0.9964 & 0.0007 & 0.0005 & -121.3 & -105.7 \\
$\mathrm{~L}$ & 0.9955 & 0.9966 & 0.0006 & 0.0004 & -123.3 & -107.7 \\
$\mathrm{~T}$ & 0.9946 & - & 0.0007 & - & -117.2 & - \\
$\mathrm{WS}$ & - & 0.9969 & - & 0.0044 & - & -103.5 \\
\hline
\end{tabular}




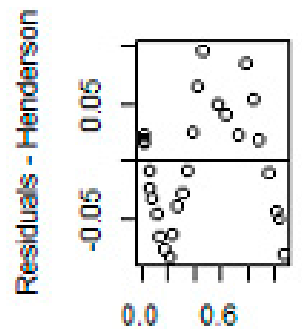

(a) Adjusted Values

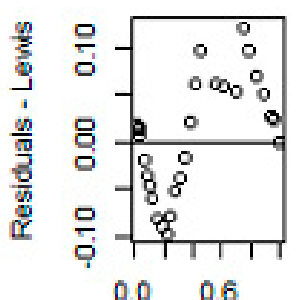

(b) Adjusted Values

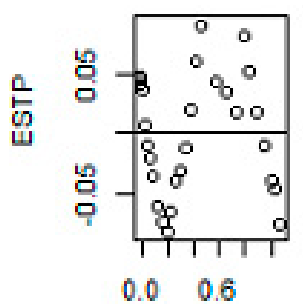

(c) Adjusted Values

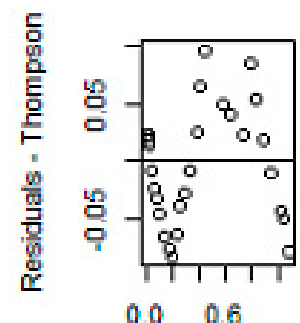

(d) Adjusted Values

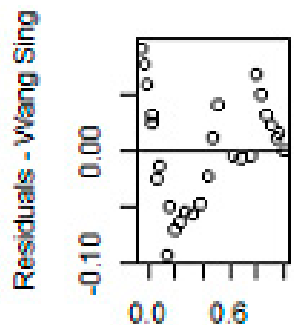

(e) Adjusted Values

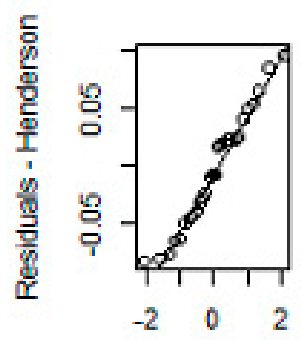

(f) Theoretical Amounts

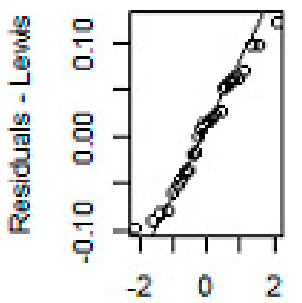

(g) Theoretical Amounts

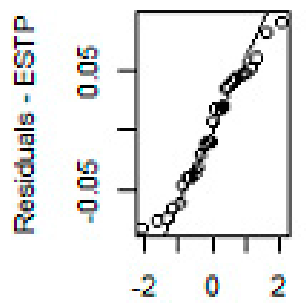

(h) Theoretical Amounts

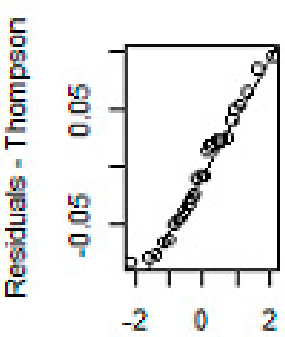

(i) Theoretical Amounts

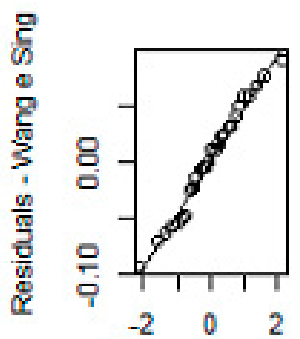

(j) Theoretical Amount:

Figure 1. Analysis of residuals for the drying kinetics of jabuticaba pulp at $50^{\circ} \mathrm{C}$, where (a), (b), (c), (d) and (e) represent the values adjusted for residuals, and in (f), (g), (h), (i) and (j), the residual values in relation to theoretical quantis for the Henderson, Lewis, Simple Three-Parameter Exponential (ESTP), Thompson and Wang and Sing models, respectively.

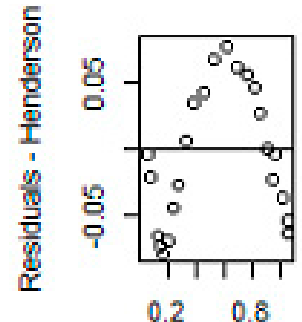

(a) Adjusted Values

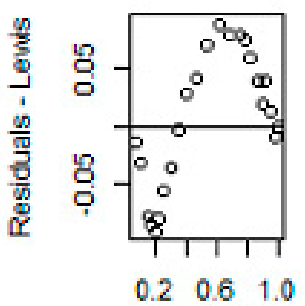

(b) Adjusted Values

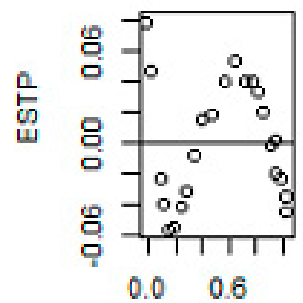

(c) Adjusted Values

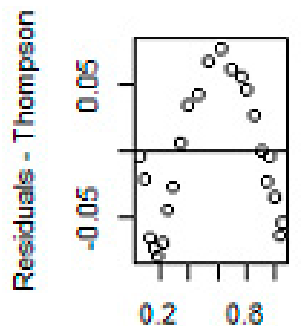

(d) Adjusted Values

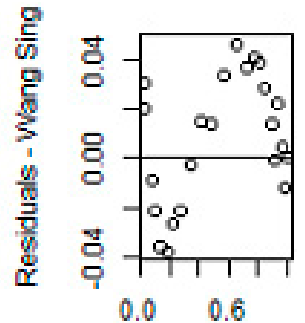

(e) Adjusted Values

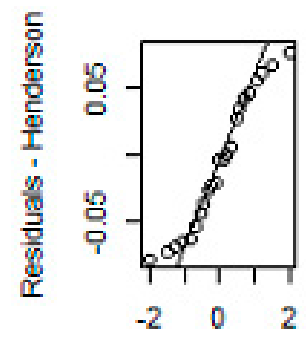

(f) Theoretical Amounts

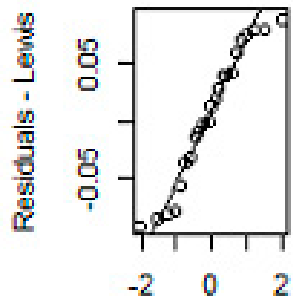

(g) Theoretical Amounts

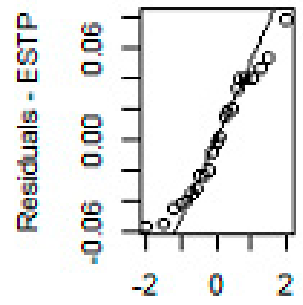

(h) Theoretical Amounts

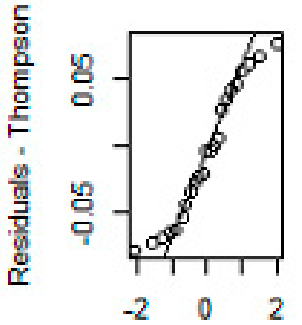

(i) Theoretical Amounts

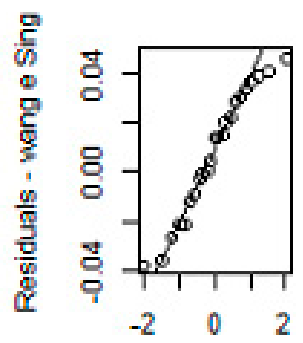

(j) Theoretical Amount

Figure 2. Analysis of residuals for the drying kinetics of jabuticaba pulp at $60^{\circ} \mathrm{C}$, where (a), (b), (c), (d) and (e) represent the values adjusted for residuals, and in (f), (g), (h), (i) and (j), the residual values in relation to theoretical quantis for the Henderson, Lewis, Simple Three-Parameter Exponential (ESTP), Thompson and Wang and Sing models, respectively. 


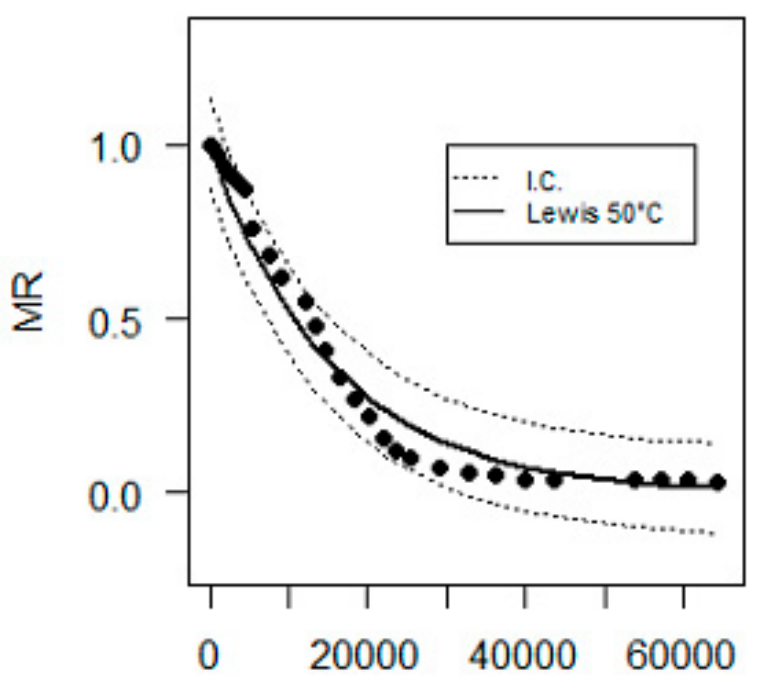

(a) Time (s)

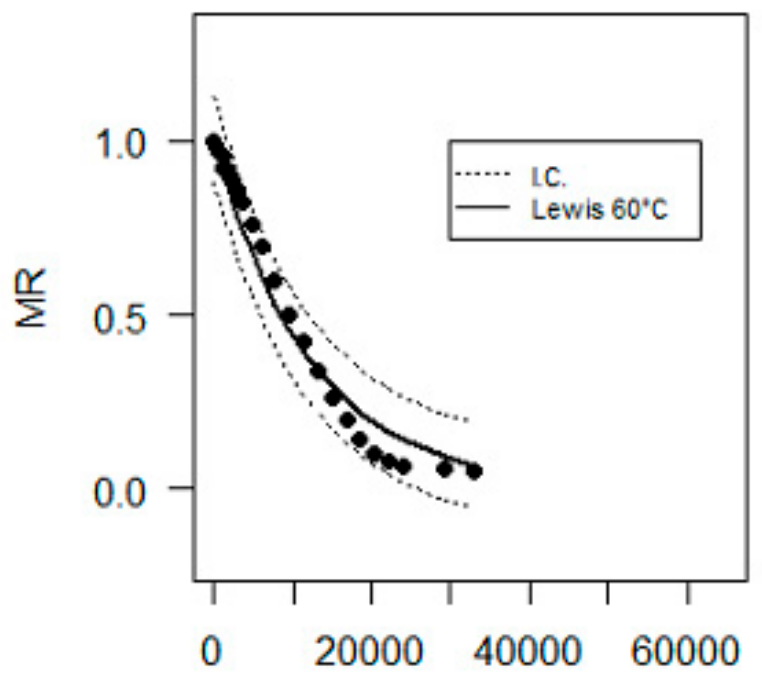

(b) Time (s)

Figure 3. Curves of Lewis model adjustments for the Moisture Ratio (MR) as a function of Time (s), the drying kinetic data of jabuticaba pulp at temperatures of $50^{\circ} \mathrm{C}$ and $60^{\circ} \mathrm{C}$ in (a) and (b) respectively.

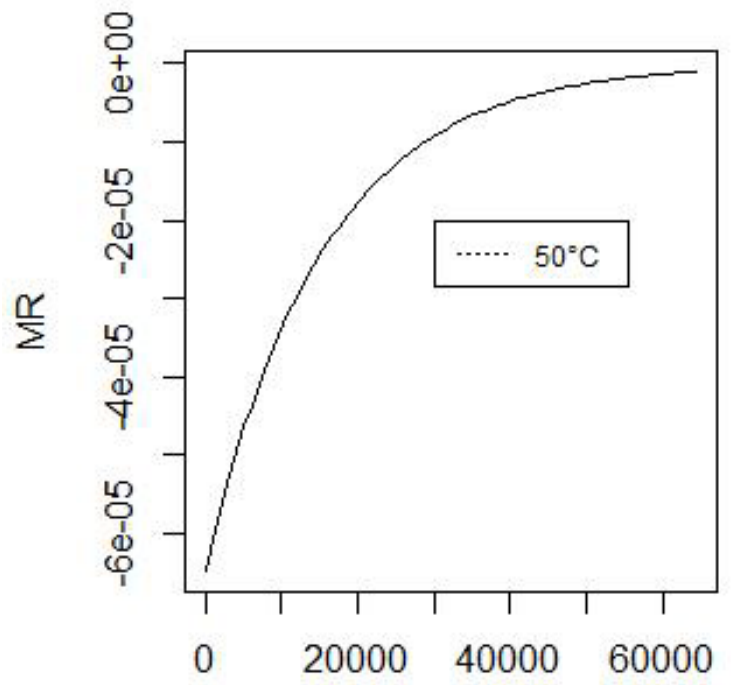

(a) Time (s)

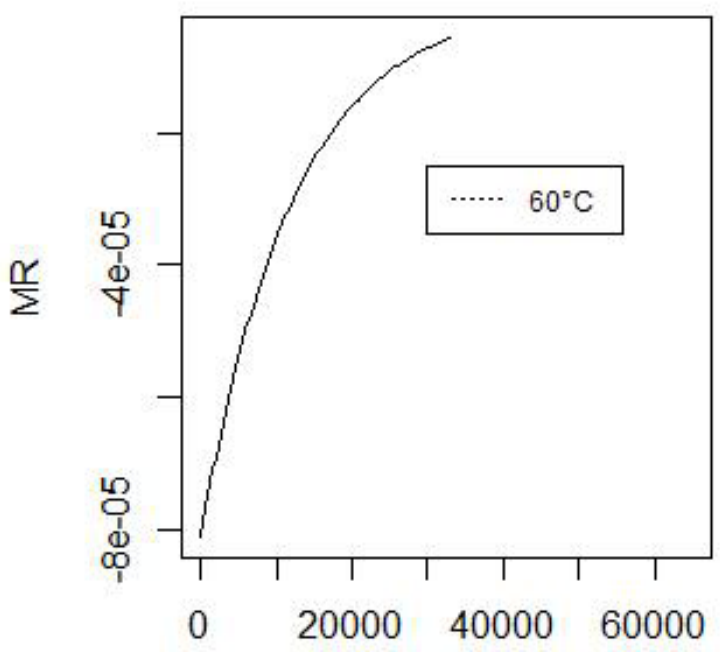

(b) Time (s)

Figure 4. Absolute drying rate relative to the Lewis model for the Moisture Ratio (MR) as a function of Time (s), for the drying kinetics data of jabuticaba pulp at temperatures of $50^{\circ} \mathrm{C}$ (a) and $60^{\circ} \mathrm{C}(\mathrm{b})$.

\section{Conclusion}

The Henderson, Lewis, Thompson and Wang Sing models presented quality adjustment to drying data of jabuticaba pulp at temperatures of 50 and $60^{\circ} \mathrm{C}$ and the Fick model did not adjust. The best model to describe data was Lewis, considering the first-order positive autocorrelation $\left(\varnothing_{1}\right)$ among residuals.
The drying rates of jabuticaba pulp at temperatures of $50^{\circ} \mathrm{C}$ and $60^{\circ} \mathrm{C}$ were $0.000063 \mathrm{~g}$ of water $/ \mathrm{s}$ and $0.000082 \mathrm{~g}$ of water/s respectively. With the Absolute Drying Rate, it was observed that in one third of the drying period, there was $70 \%$ of moisture loss at both temperatures. 


\section{Acknowledgments}

To the Federal University of Lavras (UFLA) for the development of the research, Capes and CNPq for the scholarships

\section{References}

ALVES, A.P.C.; CORREA, A.D.; LINO, J.B.R.; MARQUES, T.R. Physicochemical properties of jaboticaba skin flour stored at room temperature. Boletim CEPPA, Curitiba, v.32, n.2, p.271-280, 2014. Disponível em: $\leq$ http://dx.doi.org/10.5380/cep.v32i2.39046>. Acesso em: 5 dez. 2017.

BORGES, S.V.; MANCINI, M.C.; CORRÊA, J.L.G.; LEITE, J.B. Drying kinetics of bananas by natural convection: influence of temperature, shape, blanching and cultivar. Ciência e Agrotecnologia, Lavras, v. 35, n. 2, p. 368-376, 2011. Disponível em: $<\mathrm{http}: / /$ www. scielo.br/scielo.php? script $=$ sci arttext $\&$ pid $=\mathrm{S} 1413$ 70542011000200019\&lng $=$ en\&nrm $=$ iso $>$. Acesso em: 01 mai. 2018.

BORGES, S.V.; MANCINI, M.C.; CORRÊA, J.L.G.; NASCIMENTO, D.A. Secagem de fatias de abóboras (Cucurbita moschata, L.) por convecção natural e forçada. Ciência e Tecnologia de Alimentos, Campinas, v. 28, p.245-251, 2008. Suplemento. Disponível em: $\leq \mathrm{http}: / /$ www.scielo.br/scielo.php?script $=$ sci arttext\&pid $=\mathrm{S} 0101-$

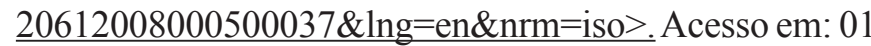
mai. 2018.

CORADIN, L.; SIMINSKI A.; REIS, A. Espécies nativas da flora brasileira de valor econômico atual ou potencial: plantas para o futuro - Região Sul. Brasília: MMA, 2011. 934p.

DALPASQUALE, V. A.; SPERANDIO, D.; KOLLING, E. M.. Performance of the Michigan drying simulation model with a new drying rate concept. Acta Scientarium. Agronomy, Maringá, v.31,n.4,p.553-557,2009. Disponível em: $<\underline{\text { http://www.scielo.br/scielo.php? script }=\text { sci }}$ arttext\&pid=S1807-86212009000400001\&lng=en\&nrm =iso $>$. Acesso em: 08 maio 2018.

EMBRAPA - Empresa Brasileira de Agropecuária Valor nutricional da jabuticaba. Colombo: Embrapa Florestas, 2015. Disponível em: $<$ https://www.embrapa.br/florestas/ busca-de-publicacoes/-/publicacao/1027136/valornutricional-da-jabuticaba $>$. Acesso em: 08 dez. 2017.
FERNANDES, T.J.; MUNIZ, J.A.; PEREIRA, A.A.;MUNIZ, F.R.; MUIANGA, C.A. Parameterization effects in nonlinear models to describe growth curves. Acta Scentiarum Technology, Maringá, v.37, n. 4, p. 397-402, 2015. Disponível em:<https://doi. org/10.4025\%2Factascitechnol.v37i4.27855>. Acesso em: 17 nov. 2017.

FERNANDES, T.J.; PEREIRA, A.A.; MUNIZ, J.A.; SAVIAN, T.V. Seleção de modelos não lineares para a descrição das curvas de crescimento do fruto do cafeeiro. Coffee Science, Lavras, v. 9, n. 2, p. 207-215, 2014.

GOBATO, M.R.S.; GOBATO, R.; HEIDARI, A. Planting of jaboticaba trees for landscape repair of degraded area. Landscape Architecture and Regional Planning, New York, v.3, n.1, p.1-9, 2018. Disponível em: $\leq$ http://www. sciencepublishinggroup.com/journal/paperinfo?journali $\mathrm{d}=241 \&$ doi $=10.11648 / \mathrm{j} .1 \mathrm{arp} .20180301 .11>$. Acesso em: 9 maio 2018.

GOUVEIA, J.P.G.; ALMEIDA, F.A.C.; FARIAS, E.S.; SILVA, M.M.; CHAVES, M.C.V.; REIS, L.S. Determinação das curvas de secagem em frutos de cajá. Revista Brasileira de Produtos Agroindustriais, Campina Grande, n.1, p.65-68, 2003.

GUEDES, M.H.P.; MUNIZ, J.A.; PEREZ, J.R.O.; SILVA, F.F.; AQUINO, L.H.de; SANTOS, C.L. dos. Estudo das curvas de crescimento de cordeiros das raças santa inês e bergamácia considerando heterogeneidade de variâncias. Ciência e Agrotecnologia, Lavras, v.28, n.2, p.381-388, 2004. Disponível em: $\leq$ http://www. scielo.br/scielo.php?script $=$ sci_arttext $\&$ pid $=S 1413$ $70542004000200019 \& \operatorname{lng}=\mathrm{en} \& \mathrm{nrm}=\mathrm{iso}>$. Acesso em: 3 jul. 2018.

MADUREIRA, I.A.; FIGUEIRÊDO, R.M.F.; QUEIROZ, A.J.M.; SILVA FILHO, E.D. Cinética de secagem da polpa do figo-da-índia. Revista Brasileira de Produtos Agroindustriais, Campina Grande, v.13, p.345-354, 2011. Número especial. Disponível em: $\leq \mathrm{http}: / / \mathrm{www}$. deag.ufcg.edu.br/rbpa/rev13e/Art13E3.pdf $>$. Acesso em: 26 mar 2018.

MAZZINI, A.R.A.; MUNIZ, J.A.; SILVA, F.F.; AQUINO, L.H. Curva de crescimento de novilhos Hereford: heterocedasticidade e resíduos autoregressivos. Ciência Rural, Santa Maria, v.35, p.422-427, 2005. Disponível em: $\leq$ http://www.scielo.br/scielo.php?script=sci arttext\&pid $=$ S0103-84782005000200028\&lng=en\&nrm =iso>. Acesso em: 1 ago. 2017. 
MAZZINI, A.R.de A.; MUNIZ, J.A.; AQUINO, L.H.de; SILVA, F.F. Análise da curva de crescimento de machos Hereford. Ciência e Agrotecnologia, Lavras, v.27, n.5, p.1105-1112, 2003. Disponível em: $\leq \mathrm{http}: / / \mathrm{dx}$.doi. org/10.1590/s1413-70542003000500019>. Acesso em: 09 maio 2018.

MORAES, S. O.; RODRIGUES, V. C. Secagem de alimentos. Piracicaba: Universidade Federal de São Paulo, 2006. 5 p.

MUIANGA, C.A.; MUNIZ, J. A.; NASCIMENTO, M da S.; FERNANDES, T.J.; SAVIAN, T.V. Descrição da curva de crescimento de frutos do cajueiro por modelos não lineares. Revista Brasileira de Fruticultura, Jaboticabal, v.38, n.1, p.22-32, 2016. Disponível em: $<$ https://doi. org $/ 10.1590 \% 2 \mathrm{~F} 0100-2945-295 \% 2 \mathrm{~F} 14>$. Acesso em: 17 nov. 2017.

MUNIZ, J.A.; NASCIMENTO, M da S.; FERNANDES, T. J. Nonlinear models for description of cacao fruit growth with assumption violations. Revista Caatinga, Mossoró, v.30, n.1, p.250-257, 2017. Disponível em: $\leq$ https://doi.org/10.1590\%2F1983-21252017v30n128rc $>$. Acesso em: 17 nov. 2017.

NUNES, J.S.; CASTRO, D.S.; MOREIRA, I.S.; SOUSA, F.C.; SILVA, W.P. Descrição da cinética de secagem de jabuticaba usando modelos empíricos. Revista Verde, Mossoró, v.9, n.1, p.20-25, jan./mar. 2014. Disponível em: $\leq$ http://www.gvaa.com.br/revista/index.php/RVADS/ article/view/2593/2001>. Acesso em: 10 set. 2017.

PENA, R.S.; MENDONÇA, N.B. Secagem em camada delgada da fibra residual do maracujá. Boletim CEPPA, Curitiba, v.27, n.2, p.257-270, 2009. Disponível em: $\leq$ http://dx.doi.org/10.5380/cep.v27i2.22036>. Acesso em: 08 fev. 2017.

PRADO, T.K.L. do; SAVIAN, T.V.; MUNIZ, J.A. Ajuste dos modelos Gompertz e Logístico aos dados de crescimento de frutos de coqueiro anão verde. Ciência Rural, Santa Maria, v.43, n.5, p.803-809, 2013. Disponível em: $\leq$ http://www.scielo.br/scielo.php?script=sci arttext\&pid=S0103-84782013000500008\&lng=en\&nrm =iso $>$. Acesso em: 23 jan. 2017.

R DEVELOPMENT CORE TEAM. R: a language and environment for statistical computing. Vienna: $\mathrm{R}$ Foundation for Statistical Computing, 2012.
RIBEIRO, T.D.; PACOPAHYBA, R.W. de M.; MORAIS, A.R. de; MUNIZ, J.A. Description of the growth of pequi fruits by nonlinear models. Revista Brasileira de Fruticultura, Jaboticabal, v.40, n.3, p., 2018b. Disponível em: < $\underline{\text { http://dx.doi.org/10.1590/0100-29452018949 > }}$ Acesso em: 05 nov. 2018.

RIBEIRO, T.D.; SAVIAN, T.V.; FERNANDES, T.J.; MUNIZ, J.A. The use of the nonlinear models in the growth of pears of 'Shinseiki' cultivar. Ciência Rural, Santa Maria, v.48, n.01, e20161097, 2018a. Disponível em: http://dx.doi.org/10.1590/0103-8478cr20161097. Acesso em: 16 jan. 2018.

SAS - Statistical Analysis System Institute. SAS procedures guide for computers. $6^{\text {th }}$ ed. Cary, 2018. v. $3,373 \mathrm{p}$.

SILVA R.B.; SILVA, F.S.; PORTO, A.G.; PILONETTO, A.A. Estudo da cinética de secagem de polpa de carambola. Revista Brasileira de Tecnologia Agroindustrial, Ponta Grossa, v.10, n.2, 2016. Disponível em: <http://dx.doi. org/10.3895/rbta.v10n2.3261>. Acesso em: 26 mar 2018.

SIQUEIRA, V.C.; RESENDE, O.; CHAVES, T.H. Mathematical modelling of the drying of jatropha fruit: an empirical comparison. Revista Ciência Agronômica, Fortaleza, v. 44, n.2, p.278-285, 2013. Disponível em: <http://www.scielo.br/scielo.php?script=sci arttext\&pid=S1806-66902013000200009\&lng=en\&nrm =iso $>$. Acesso em: 02 mar. 2017.

TACO. Tabela brasileira de composição de alimentos. 4.ed. Campinas: Núcleo de Estudos e Pesquisas em Alimentação, Universidade Estadual de Campinas, 2011. Disponível em: $\leq$ http://www.nepa.unicamp.br/taco/tabela. php?ativo=tabela $>$. Acesso em: 05 maio 2018.

VIEIRA, D.F.; CONSTANTINO, J.S.F.; RODRIGUES, L.M.de S.; SILVA, L.P.F.R.da; ALMEIDA, R.D. Avaliação físico-química e de textura instrumental de geleia mista de jabuticaba e pitanga. Revista Brasileira de Agrotecnologia, Garahuns,v.7, n.2, p.407-410, 2017. Disponível em: $<$ http://www.gvaa.com.br/revista/index. php/REBAGRO/article/view/5241/407-411>. Acesso em: 08 dez. 2017. 
WARNES, G. R.; BOLKER, B.;BONEBAKKER, L.; GENTLEMAN, R.; LIAW, W. H. A.; LUMLEY, T.; MAECHLER, M.; MAGNUSSON, A.; MOELLER, S.; SCHWARTZ, M.; VENABLES, B. G plots: various $r$ programming tools for plotting data. $\mathrm{R}$ package version 3.0.1. 2016. Disponível em: $\leq$ https://CRAN.R-project.org/ package $=$ gplots $>$. Acesso em: 23 out. 2018.
ZICKER, M. C. Obtenção e utilização do extrato aquoso de jabuticaba (Myrciaria Jabuticaba (vell) berg) em leite fermentado: caracterização físicoquímica e sensorial. 2011. 138 f. Dissertação (Mestrado em Ciência dos Alimentos) - Universidade Federal de Minas Gerais, Belo Horizonte, 2011. 